\title{
Sustainability of cacao farms in the district of Huicungo (San Martín, Perú) with the "rapid agroecological method"
}

\author{
Sustentabilidad de fincas cacaoteras en el distrito de Huicungo (San Martín, Perú) \\ con el "Método Agroecológico Rápido"
}

\author{
Tuesta, O. ${ }^{1}$; Santistevan, M. ${ }^{1}$; Borjas, R. ${ }^{1}$; Castro, V. ${ }^{2}$; Julca, A. ${ }^{1 *}$ \\ *Corresponding author: ajo@lamolina.edu.pe
}

\begin{abstract}
This work was carried out with the objective to determine the sustainability of cocoa farms in the district of Huicungo (San Martín, Perú) by using the "Rapid Agroecological Method". The study was conducted in the San Martín region, province of Mariscal Cáceres, district of Huicungo. The zone has an annual precipitation of 1, $200 \mathrm{~mm}$ and an annual temperature of $30^{\circ} \mathrm{C}$. For the sustainability analysis, we selected "type farms" from each of the three groups found in the area. In each of these, indicators of soil quality and crop health were evaluated using values ranging from 1 to 10 (1: less sustainable, 10: more sustainable). With the collected data, Duncan Test $(p \leq 0.05)$ was performed to determine the statistical differences between the "type farms". Results showed the evaluated cacao farms had values greater than five, therefore, they are sustainable. There were no statistical differences between the three "type farms" studied here.
\end{abstract}

Keywords: sustainability, farms, soil, health, cultivation.

\section{Resumen}

Este trabajo se llevó a cabo con el objetivo de determinar la sostenibilidad de las fincas de cacao en el distrito de Huicungo (San Martín, Perú) utilizando el "Método Agroecológico Rápido". El estudio se realizó en la región de San Martín, provincia de Mariscal Cáceres, distrito de Huicungo. La zona tiene una precipitación anual de 1,200 mm y una temperatura anual de $30^{\circ} \mathrm{C}$. Para el análisis de sostenibilidad, seleccionamos "fincas tipo" de cada uno de los tres grupos encontrados en el área. En cada uno de estos, los indicadores de la calidad del suelo y la salud del cultivo se evaluaron utilizando valores que van de 1 a 10 (1: menos sostenible, 10: más sostenible). Con los datos recopilados, se realizó la prueba de Duncan $(\mathrm{p} \leq 0.05)$ para determinar las diferencias estadísticas entre las "fincas tipo". Los resultados mostraron que las fincas de cacao evaluadas tenían valores superiores a cinco, por lo tanto, son sostenibles. No hubo diferencias estadísticas entre las tres "fincas tipo" estudiadas aquí.

Palabras Claves: sustentabilidad, fincas, calidad, suelo, salud, cultivo.

\section{Introduction}

The sustainability of agriculture can be defined as the capacity of an agroecosystem to maintain the quality and quantity of natural resources in the medium and long term, reconciling agricultural productivity with the reduction of impacts on the environment and considering social needs of rural communities (Brown, 1987 cited by Zinck et al., 2004). Other authors, cited by Gómez-Limón et al. (2011), define sustainable agriculture as the one that promotes food security, conserves natural resources, protects the environment and is economically viable. To evaluate sustainability, the use of mathematical models, time series, indicators, among others have been suggested (Gómez-Limón et al., 2011). According to De Muner (2011), sustainability evaluation studies of production systems that use indicators turned out to be an effective tool for evaluating the ecological, economic and social sustainability of agricultural production systems, as in the case of the family production system of Arabica coffee in Espírito Santo in Brazil. Meza and Julca (2015) have also used indicators to evaluate cassava cropping systems in Cusco, Perú. Recently, they have also used indicators in Ecuador to evaluate productive units in the Amazon (Bravo-Medina et al., 2017). But there are also authors who indicate that sustainability indicators, in general, cannot be considered universal, and due to the way of inferring the conditions of an agroecosystem, they are not commonly used by farmers (Gómez et al., 1996, Masera, 1999). There are other methodologies that allow the comparison of farms sustainability independently

\footnotetext{
${ }^{1}$ Departamento de Fitotecnia, Facultad de Agronomía, Universidad Nacional Agraria La Molina, Av. La Molina s/n, Lima 12, Perú.

${ }^{2}$ Facultad de Ciencias, Universidad Nacional Agraria La Molina, Av. La Molina s/n, Lima 12, Perú.
} 
from the existing situations. For example, Altieri and Nicholls (2002), proposed a rapid agroecological method for sustainability evaluation of coffee plantations and has been used by Merma and Julca (2012) to evaluate the sustainability of diverse production systems in Cusco (Perú). However, this method only evaluates the quality of the soil and the health of the crop, and it does not consider the three dimensions of sustainability (Márquez and Julca, 2015). But it is a relatively simple tool, its use can be extended and its practicity widespread between farmers and field technicians, especially for preliminary studies of sustainability of agricultural production systems.

In Peru, cacao (Theobroma cacao) is a crop of great importance and there are several regions that have edaphoclimatic conditions that favor the development of this crop, as is the case of San Martín (Arévalo et al., 2004). The crop is grown under shade in agroforestry systems, associated almost exclusively with small producers and has always been used in alternative development programs in coca-growing areas. This work was carried out with the objective of knowing the sustainability of cacao farms in the district of Huicungo (San Martín, Peru) with the "rapid agro-ecological method".

\section{Materials and Methods}

This study was carried out in the middle part of the subbasin of the Huayabamba River, located in the San Martín region, province of Mariscal Cáceres, Huicungo district. The area is a tropical humid forest (bh-t), with an average annual rainfall of 1,200 $\mathrm{mm}$, an average annual temperature of $30^{\circ} \mathrm{C}$, a maximum annual average of $35^{\circ} \mathrm{C}$, and the minimum annual average is $23.2^{\circ} \mathrm{C}$. For the sustainability analysis, we selected three "type farms" from each of the three groups that exist in the area. Group I (68\% of the farms), is characterized by developing other activities parallel to the cultivation of cacao, has a conventional production system, with polyclonal plantations and a yield of $963 \mathrm{~kg} / \mathrm{ha}$. Group II (13\% of farms) basically has organic production farms, where hybrid plantations associated with CCN51 predominate, with a yield of $623 \mathrm{~kg} / \mathrm{ha}$. In group III (19\% of the farms), monoclonal plantations exist using only CCN-51, with a yield of $933 \mathrm{~kg} / \mathrm{ha}$ (Tuesta et al., 2014). Studies using "type farms" have been carried out by Salazar (2012), Collantes (2016) and Santistevan et al. (2017). Indicators of soil quality and health of the cacao crop were evaluated in each of the "type farms". Each indicator can have values ranging from 1 to 10 , with 1 being the least sustainable value and 10 the most sustainable value. The valuation given to each indicator was validated with producers and professionals with experience with this crop. The indicators used in the present study were obtained from the proposal of Altieri and Nicholls (2002) and Araujo et al. (2008). Details are shown in Table 1. With the collected data, a Duncan Test $(p \leq 0.05)$ was performed to determine the statistical differences between the "type farms". Subsequently, amoeba graphics were made for soil quality and crop health.

\section{Results and Discussion}

Soil quality - In general terms, a different behavior of soil quality was found in each "type farm"; but type II, had higher values for half of the indicators evaluated as CS3 (color, smell and organic matter), which logically is related to CS4 (moisture retention), CS6 (lower risk of erosion), CS7 ( structure) and CS10 (microbial activity). This is important, because the physical properties of the soil and the organic matter content of the soils are the variables with the greatest contribution to the integral fertility, suggesting an adequate physical and biological condition, which helps the penetration and development of roots. Hence, they favor the use of nutrients and water in the soil (Power, 2010, Viana et al., 2014, Bravo et al., 2015, cited by BravoMedina et al., 2017). The structure and moisture retention are favored by the presence of organic matter (Julca et al., 2006). Soil quality had average values greater than five, although practically similar to each other $(6.99,7.04$ and 6.97, for "type farms" I, II and III, respectively), so there were no statistical differences between them, as shown in table 2 and illustrated in figure 1. These results are explained as a response to the fact that cacao cultivation is mainly developed under an agroforestry system, being the one that most resembles a natural forest (Müller, 2006). Somarriba (2006), points out that agroforestry systems promote the conservation and fertility of soils, besides being the best form of land use in tropical climates (Lobão et al., 2004) and recommended for organic production. Other authors state that organic production has a positive impact on soil quality, on the amount of microorganisms (Hole et al., 2005) and can reduce soil erosion (Arnhold et al., 2014). Larrea (2007) and Araujo et al. (2008), report a partial sustainability in agroforestry systems with cocoa using indicators for the soil.

Crop health-It was different in each "type farm". Farm type I, had higher values for most of the indicators studied, with the exception of SC3 (damage incidence) and SC7 (management system), which was better for type III and II, respectively. The average values were greater than five, although the "farm types" I (6.56) and III (6.28) were statistically superior to type II (5.76). But, there are still some aspects that can be improved by performing some cultural activities that could improve the performance of the crop in general, as shown in Figure 1. For example, Pria and Camargo (1997), point out that pruning is one of the ways to control many diseases in the cultivation of cacao. In other crops of the tropics, such as coffee, its effect has also been demonstrated to reduce the incidence levels of rust (Rafael-Rutte et al., 2014). The development of suitable technological practices and their application by the grower helps to improve yield and quality of cacao (PROAMAZONÍA, 2003). The potential of cacao will be exhibited by using profitable and sustainable technologies to guarantee the livelihood of the grower now and in the future (IICA, 2006). 
Tabla 1. Indicators for the rapid evaluation of cacao farms in Huicungo (San Martín, Perú)* considering soil quality and crop health

\begin{tabular}{|c|c|c|}
\hline \multicolumn{3}{|r|}{ Soil quality (SQ) } \\
\hline Indicator & $\begin{array}{l}\text { Established } \\
\text { value }\end{array}$ & Characteristics \\
\hline \multirow{3}{*}{ SQ1. Compaction } & 1 & Compacted soil \\
\hline & 5 & Thin compacted layer \\
\hline & 10 & No compaction \\
\hline \multirow{3}{*}{ SQ2. Soil depth } & 1 & Exposed subsoil \\
\hline & 5 & Thin superficial soil \\
\hline & 10 & Superficial soil $>1 \mathrm{~m}$ \\
\hline \multirow{3}{*}{ SQ3. Organic matter color } & 1 & Pale, no presence of humus \\
\hline & 5 & Light brown, some presence of humus \\
\hline & 10 & Dark brown, abundant humus \\
\hline \multirow{3}{*}{ SQ4. Moisture retention } & 1 & Dry soil, does not hold water \\
\hline & 5 & Limited moisture level available or short time \\
\hline & 10 & Reasonable moisture level for a reasonable period of time \\
\hline \multirow{3}{*}{ SQ5. Soil cover } & 1 & No cover, $100 \%$ exposed \\
\hline & 5 & Less than $50 \%$ soil covered by residues \\
\hline & 10 & More than $50 \%$ soil covered by residues \\
\hline \multirow{3}{*}{ SQ6. Erosion } & 1 & Severe erosion \\
\hline & 5 & Low erosion signs \\
\hline & 10 & No visible signs of erosion \\
\hline \multirow{3}{*}{ SQ7. Structure } & 1 & Loose, powdery soil without visible aggregates \\
\hline & 5 & Few aggregates that break with little pressure \\
\hline & 10 & Well-formed aggregates - difficult to break \\
\hline \multirow{3}{*}{ SQ8. Status of residues } & 1 & Slowly decomposing organic residues \\
\hline & 5 & Presence of last year's decomposing residues \\
\hline & 10 & Most residues well-decomposed \\
\hline \multirow{3}{*}{$\begin{array}{l}\text { SQ9. Presence of } \\
\text { invertebrates }\end{array}$} & 1 & No signs of invertebrate presence or activity \\
\hline & 5 & A few earthworms and arthropods present \\
\hline & 10 & Abundant presence of invertebrate organisms \\
\hline \multirow{3}{*}{$\begin{array}{l}\text { SQ10. Microbiologic } \\
\text { activity }\end{array}$} & 1 & Very little effervescence after application of water peroxide \\
\hline & 5 & Light to medium effervescence \\
\hline & 10 & Abundant effervescence \\
\hline \multicolumn{3}{|r|}{ Crop health $(\mathrm{CH})$} \\
\hline \multirow{3}{*}{$\begin{array}{l}\text { CH1. Appearance of the } \\
\text { crop }\end{array}$} & 1 & Chlorotic, discolored foliage with deficiency signs \\
\hline & 5 & Light green foliage with some discoloring \\
\hline & 10 & Dark green foliage, no signs of deficiency \\
\hline \multirow{3}{*}{$\mathrm{CH} 2$. Crop growth } & 1 & Uneven stand; short and thin branches; limited new growth \\
\hline & 5 & Denser. but not uniform stand; thicker branches; some new growth \\
\hline & 10 & Abundant branches and foliage; vigorous growth \\
\hline \multirow{3}{*}{ CH3. Damage incidence } & 1 & Susceptible, more than $50 \%$ of plants with damaged leaves and/or fruits \\
\hline & 5 & Between $20-45 \%$ plants with damage \\
\hline & 10 & Resistant, with less than $20 \%$ of plants with light damage \\
\hline \multirow{3}{*}{ CH4. Insect pest incidence } & 1 & More than 15 leafhopper nymphs per leaf, or more than $85 \%$ damaged leaves \\
\hline & 5 & Between 5-14 leafhopper nymphs per leaf, or 30-40\% damaged leaves \\
\hline & 10 & Less than 5 leafhopper nymphs per leaf, and less than $30 \%$ damaged leave \\
\hline \multirow{3}{*}{$\begin{array}{l}\mathrm{CH} 5 \text {. Actual or potential } \\
\text { yield }\end{array}$} & 1 & Low in relation to local average \\
\hline & 5 & Medium, acceptable \\
\hline & 10 & High, above average \\
\hline \multirow{3}{*}{$\begin{array}{l}\text { CH6. Vegetational } \\
\text { diversity }\end{array}$} & 1 & Monoculture \\
\hline & 5 & 2-3 clones with low number of tree species \\
\hline & 10 & More than 5 clones and more than 10 tree species \\
\hline
\end{tabular}


Continuation table 1

\begin{tabular}{lcl}
\hline & 1 & Conventional \\
CH7. Management system & 5 & In transition to organic with IPM or input substitution \\
& 10 & Organic, diversified with low external biological inputs \\
& 1 & Not using them, put them where harvest ocurred \\
CH8. Harvest residue & 5 & Residues are collected, but not use them \\
& 10 & Uses all residues, humus is produced \\
\hline
\end{tabular}

*Adapted from de Araujo et al., (2008), and Altieri and Nicholls (2002)

Table 2. Soil quality of "type farms" with cacao in Huicungo (San Martín)

\begin{tabular}{lccc}
\hline \multicolumn{1}{c}{ Indicators } & Type farms I & Type farms II & Type farms III \\
\hline Compaction & 7.80 & 7.40 & 7.20 \\
Soil depth & 6.40 & 6.20 & 6.60 \\
Color, odor, ad organic matter & 5.50 & 6.20 & 5.80 \\
Moisture retention & 8.60 & 9.10 & 8.80 \\
Soil cover & 7.20 & 6.50 & 7.10 \\
Erosion & 5.20 & 6.20 & 5.80 \\
Structure & 6.50 & 7.40 & 7.00 \\
Status of residues & 7.40 & 6.10 & 7.20 \\
Presence of invertebrates & 7.80 & 7.10 & 7.20 \\
Microbiological activity & 7.50 & 8.20 & 7.00 \\
Average soil quality & $6.99 \mathrm{a}$ & $7.04 \mathrm{a}$ & $6.97 \mathrm{a}$ \\
\hline
\end{tabular}

Same letter indicate significative difference, according to Duncan test $(\mathrm{p} \leq 0.05)$

Table 3. Crop health of "type farms" with cacao in Huicungo (San Martín)

\begin{tabular}{lccc}
\hline \multicolumn{1}{c}{ Indicators } & Type farms I & Type farms II & Type farms III \\
\hline Appearance & 6.2 & 6 & 6 \\
Crop growth & 7.8 & 7.1 & 7.8 \\
Disease incidence & 8.5 & 7.5 & 8.9 \\
Insect pest incidence & 7.4 & 5.2 & 7 \\
Actual or potential yield & 9.2 & 6 & 9 \\
Vegetational diversity & 5.4 & 4 & 3.5 \\
Management system & 3 & 6.7 & 3 \\
Harvest residues & 5 & 3.6 & 5 \\
Average crop health & $6.56 \mathrm{a}$ & $5.76 \mathrm{~b}$ & $6.28 \mathrm{a}$ \\
\hline
\end{tabular}

Same letter indicate significative difference, according to Duncan test $(p \leq 0.05)$

If we do the exercise of obtaining the average for each farm [(CS + SC) / 2], we obtain values of 6.8, 6.4 and 6.6 for farms type I, II and III, respectively. The three groups exceed the value of five, considered as the "threshold of sustainability" (Altieri and Nicholls, 2002), meaning that all cacao farms evaluated with the "rapid agro-ecological method" can be considered sustainable. This can be explained due to the work conducted for years in the San Martin region with the cultivation of cacao since the development of sustainable production systems implies a continuous adaptation to local or regional socioeconomic and ecological circumstances (Nieto and Caicedo, 2012).

The method used in the present study is relatively simple and can be used by farmers and field technicians, especially for preliminary sustainability studies of agricultural production systems. Because sustainability studies should have a broader criterion always considering the three dimensions of sustainability (Márquez and Julca, 2015).

\section{Conclusions}

Using the "rapid agro-ecological method", the cacao farms of Huicungo (San Martín) are sustainable. The method is relatively simple and can be used especially for preliminary sustainability studies of agricultural production systems.

\section{References}

Altieri, M.; Nicholls, C. 2002. Un método agroecológico rápido para la evaluación de sustentabilidad de cafetales. Manejo Integrado de Plagas y Agroecología 64: 17-24.

Araujo, R.; Araujo, P.; Ney, M. 2008. Indicadores de sustentabilidad para evaluar la

calidad del suelo y la salud del cultivo. Ilhéus, CEPLAC/CEPEC. Boletín Técnico $\mathrm{N}^{\circ} 193.24$ p.

Arévalo, E.; Zúñiga, L.; Arévalo, C.; Adriazola, J. 2004. Cacao, manejo integrado del cultivo y transferencia 
de tecnología en la Amazonía peruana. Instituto de Cultivos Tropicales. Tarapoto. Perú. 184 pp.

Arnhold, S.; Lindner, S.; Lee, B.; Huve, B. 2014. Conventional and organic farming:

soil erosion and conservation potential for row crop cultivation. GEODERMA 219-220, 89-105.

Bravo-Medina, C.; Marín, H.; Marrero-Labrador, P.; Ruiz, M. Torres-Navarrete, B.; Navarrete-Alvarado, H.; Durazno-Alvarado, G. \& Changoluisa-Vargas, D. 2017. Evaluación de la sustentabilidad mediante indicadores en unidades de producción de la provincia de Napo, Amazonía Ecuatoriana. Bioagro 29 (1):2336 .

Collantes, R. 2016. Sustentabilidad de los agroecosistemas de palto (Persea americana MiLL.) y mandarina (Citrus spp.) en Cañete, Lima, Perú. Revista Tecnología y Desarrollo, 13(1): 027-034.

De Muner, L.H. 2011. Sostenibilidad de la caficultura arábica en el ámbito de la agricultura familiar en el estado de Espírito Santo-Brasil. Tesis Doctoral. Universidad de Córdoba. España. 262 pp.

Gómez-Limón, J. \& Arriaza, M. 2011. Evaluación y sustentabilidad de las explotaciones de olivar en Andalucía. Analistas Económicos de Andalucía. Málaga. España. 294 pp.

Márquez, F. y Julca, A. 2015. Indicadores para evaluar la sustentabilidad en fincas cafetaleras en Quillabamba. Saber \& Hacer 2(1): 128- 137.

Meza, I. y Julca, A. 2015. Sustentabilidad de los sistemas de cultivo con yuca (Manihot esculenta crantz) en la subcuenca de Santa Teresa, Cusco. Ecología Aplicada 14 (1): 55-63.

Gómez, A.; Kelly, S.; Syers, K.; Coughland, J. 1996. Measuring sustainabilty of agricultural systems at farm level. In: Methods for assessing soil quality. SSSA Special Pub.49, Madison, Wisconsin. Pp. 401409.

Hole, D.; Perkins, A.; Wilson, J.; Alexander, I.; Grice, P.; Evans. 2005. Does organic farming benefit biodiversity? Biological conservation 122: 113-130.

Instituto Interamericano de Cooperación para la Agricultura-IICA. 2006. Protocolo Estandarizado de oferta Tecnológica para el Cultivo de Cacao en el Perú. Lima - Perú. 73 p.

Julca, A.; Meneses, L.; Blas, R.; Bello, S. 2006. La materia orgánica, importancia y experiencia de su uso en la agricultura. IDESIA 24(1): 49-61.

Merma, I. y Julca, A. 2012. Tipología de productores y sostenibilidad de cultivos en

Alto Urubamba, La Convención - Cusco. Scientia Agropecuaria 3 (2): 149-159.

Larrea, C. 2007. Determinación de las reservas de carbono en la biomasa aérea de combinaciones agroforestales de Theobroma cacao L. y determinación de la ecuación alométrica para el cacao. Tesis de maestría. UNALM 12 $146 \mathrm{pp}$.
Lobão, D.; Setenta, W.; Valle, R. 2004. Sistema agrossilvicultural cacaueiro-modelo de agrocultura sustentável. Agrossilvicultura 1(2): 163-173.

Masera O. 1999. Sustentabilidad y manejo de los recursos naturales. El marco de evaluación MESMIS. Mundiprensa, México. 109 pp.

Müller, M. 2006. Importância dos sistemas agroflorestais para a sustentabilidade dos biomas tropicais En: $28^{\mathrm{a}}$ Semana del fazendeiro. Ministério de agricultura pecuária e abastecimiento. Brasil. 219 pp.

Nieto, C. y C. Caicedo. 2012. Análisis reflexivo sobre el desarrollo agropecuario sostenible de la Amazonía Ecuatoriana. INIAP-EECA. Publicación Miscelánea $\mathrm{N}^{\circ}$ 45. Joya de los Sachas. Ecuador. 102 pp.

Pria, M; Camargo, L. 1997. Doenças do cacaueiro En: Manual de fitopatología, vol II: Doenças de plantas cultivadas. Escola Superior de Agricultura Luiz de Queiros. Universidade de São Paulo. Brasil. 705 pp.

PROAMAZONIA. 2003. Caracterización de las zonas productivas de cacao en el Perú y su competitividad. Ministerio de agricultura. Perú. 221 pp.

Rafael-Rutte, R.; Julca, A. y Rivera, R. 2014. Alturas de poda y fertilización en la renovación de plantaciones de cafe (Coffea arabica L.) en la selva central del Perú. Chilean J. Agric. Anim. Sci., ex Agro-Ciencia 30(3): 191-201.

Somarriba, E. 2006. Como analizar y mejorar la sombra en los cacaotales. CATIE, Bolivia. Taller Regional de Aplicación Tecnológica en el cultivo del cacao. ACCESO, IICA, USAID, WCF, CICAD/OEA. 6-8 marzo 2006

Salazar, R. 2012. Caracterización de sistemas agroecológicos para el establecimiento comercial de cacao orgánico (Theobroma cacao) en Talamanca. Revista Tecnología en Marcha, 25 (5): 45-54.

Santistevan M.; Helfgott, S.; Loli, O. y Julca, A. 2017. Comportamiento del cultivo del limón (Citrus aurantifolia Swingle) en "fincas tipo" en Santa Elena, Ecuador. Idesia (Arica) 35 (1): 45-49.

Tuesta, O.; Julca, O.; Borjas, R.; Rodríguez, P.; Santistevan, M. 2014. Tipología de fincas cacaoteras en la subcuenca media del río Huayabamba, distrito de Huicungo (San Martín, Perú). Ecología Aplicada 13(2): 71-78.

Zinck, J.A.; Berroterán, J.L.; Farshad, A.; Mamen, A.; Wokabi, S.; Van Ranst, E. 2004. Approaches to assessing sustainable agriculture of Sustainable Agriculture, 23(4): 87-109. 

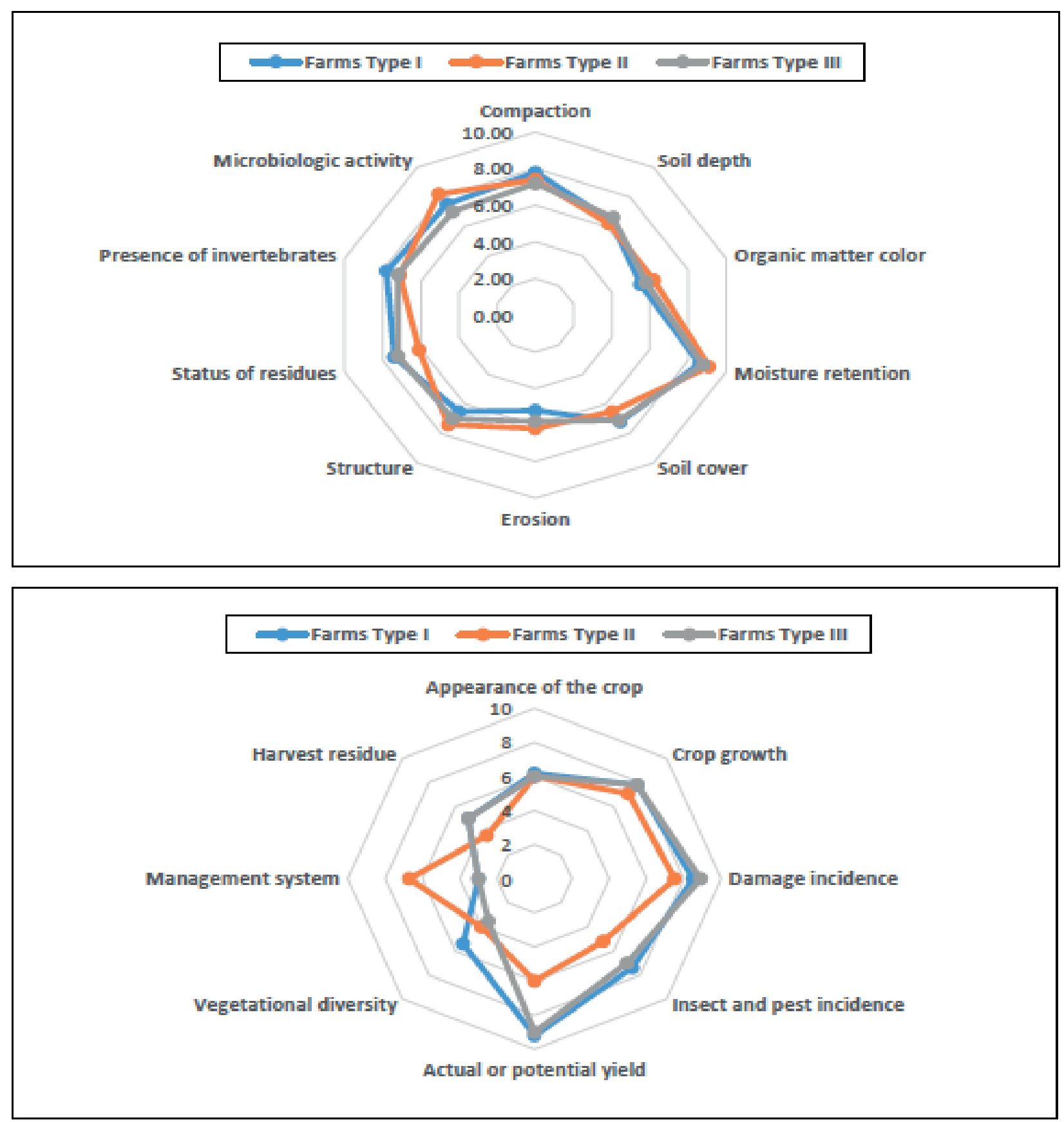

Figure 1. Soil quality (top) and crop health (bottom) of cacao farms in Huicungo (San Martín) 